\title{
DEVELOPMENT STRATEGIES AND TRANSFORMATION OF THE REGION'S INDUSTRIAL COMPLEX
}

\author{
Olga Grozova*, Galina Tsvetkova, Veronika Maslikhina \\ Volga State University of Technology, Russian Federation
}

The aim of the study is to analyze the industrial complex transformation of the provincial region and determine the prospects for its development. The economic potential of industrial complex of the Mari El Republic of Russia is analyzed. The structural and dynamic analysis of the region's manufacturing industry, as well as the analysis of its material and technical base, investment, innovation and human resources is carried out. High depreciation of fixed assets of industry prevents its successful transformation. The high impact of the investment level on the growth rate of the manufacturing industry has been revealed. The low level of region's innovative potential has no impact on the manufacturing industry development. The personnel potential of the region's industry is characterized by the outflow of personnel with higher education and the availability of personnel with labour occupations.

The development strategies of the region's industrial complex are considered. High-tech enterprises of the region (IT-sphere, enterprises for the electrical equipment production, electronic and optical equipment production) can implement an offensive strategy of innovative development. The intermediate strategy and import substitution strategy are substantiated as actual strategic decisions for the enterprises of medium and low-tech industry sectors. They can provide competitive positions of the region's industry.

Key words: industrial complex potential, manufacturing industry, innovation, investment, transformation, Russia, the Mari El Republic

\section{INTRODUCTION}

Global economic and social transformations have a significant impact on the country's industrial policy, the structure of the region's industrial complex. The key provisions of industrial policy of Russia, which determine the transformation vector of the region's technological complex, are set out in the State program "Development of industry and increasing its competitiveness"[1], the Information Society Development Strategy of the Russian Federation [2], the Action Plan ("road map") "TechNet" (advanced production technologies) of the National technological initiative [3]. The presented documents are institutional factors of transformation of the regional industry. The industrial complex of the region is an open socio-economic system, so it changes under the influence of technological drivers of Industry 4.0., as well as the economic and social dynamic which is characteristic for the Russian economy. However, the spatial organization of the domestic economy and the uneven socio-economic development of the regions determine significant differences of the regional industrial systems. Based on the concept of economic zoning proposed by a Russian scientist N. N. Kolosovsky, the regional industrial complex will be understood as territorial organization of economic activity or a complex of enterprises in one regional space [4]. This set of production systems generates a certain economic effect due to the structural profile of the region, based on historical, political, economic, and social conditions of the region and taking into account its economic and geographical position. The classical un- derstanding of the region's industrial complex as a meso-level production system implies a set of interrelated and interdependent production systems of enterprises.

The transformation of the industrial complex includes a "strong-willed, creative beginning", since the participants of this process are such subjects as state institutions, industrial enterprises, entrepreneurs [5]. At the same time, business processes and operational efficiency of production systems are changing, and organizational and technical models of industrial enterprises are being transformed [6]. Thus, the transformation of the region's industrial complex is a change in form and content of its production systems. It is the result of its adaptation to external influences and local conditions of the territory development. Currently, the Russian model of spatial development gives priority to the principles of competitive economy. This necessitates the development of the competitive potential of the territory in determining the transformational vector of the region's industrial complex. All this determines the relevance of the study of the transformation of the provincial region's industrial complex.

The theoretical and methodological basis of the study is the research of European and Latin American scientists on the economy technological structure modernization and the impact of innovation policy on the economic growth of the territories. Among them, the model of "peripheral capitalism" by R. Prebisch [7], the theory of growth poles by F. Perroux [8], the theory of economic growth stages by W. Rostow [9], innovation theory by 
G. Mensch [10] and researches of reconversion processes in industry and dynamics of regional development by J. Sapir [11]. The concept of change management (Transition Management) by R. Kemp allowed to include in the analysis the tools of technical policy that set the trajectory of changes in the region [12]. Studies of industry concentration in European countries by Á. Hegyi-Kéri had a significant impact on the understanding of the transformation of the region's production system [13]. The authors relied on the conclusions of Serbian scientists about the need to benefit from European experience and lessons in the design of strategies for the development of industrial sector [14].The authors found extremely interesting the findings of researchers that since the early 1990s the European economy has not seen a strengthening of the impact of high-tech production on economic growth [15]. There is a valuable remark of Croatian scientists that the factors of influence on the industry transformation in developed European countries and post-Communist economies are critically different [16]. The conclusions of Serbian scientists about the multidimensional nature of the transformation process and the insufficiency of its measurement only from the point of view of the absolutely decline in employment in the industry deserve attention [17]. We believe that the conclusion of European scientists that the transformation process of the industrial sector should be considered not just as a result of positive economic trends is fair. The industrial sector transformation process is influenced by various non-economic factors [18].

The authors relied on the conceptual provisions of the socio-economic systems transformation, presented in the works of Russian scientists S. Glazyev [19], V. Polterovich [20] and Y. Yakovets [5], as well as works of the efficiency of production systems by G.Kleiner [21] and O. Sukharev [22], researches of the concentration of the Russian manufacturing industry by V. Maslikhina [23]. The analysis of practical researches of scientists allows to speak about return of priorities of material production, the basis of which is the industrial complex of the region. the industrial complex of the provincial region and determine the prospects for its development through the case of the industrial complex of the Mari El Republic of Russia.

\section{Information base and research methods}

The information base of the study is the data of Federal State Statistics Service of the Russian Federation(Rosstat)[24], the Territorial Department of the Federal State Statistics Service for the Mari El Republic[25], Ranking of Innovative Regions of Russia, developed by AIRR[26], and Ranking of the National report "High-tech business in the Russian regions", prepared jointly by RANEPA, AIRR and Interfax group [27]. Statistical information on the development of the industrial complex of the Mari El Republic from 2010 to 2018 was processed. Structural-dynamic and correlation analysis were used as research methods.

\section{RESULTS AND DISCUSSION}

\section{Analysis of the Mari El Republic industrial complex}

The Mari El Republic is a subject of the Russian Federation, is a part of the Volga Federal district (VFD). The Mari EI Republic is a provincial region. It has a small area of $23375 \mathrm{sq}$. $\mathrm{km}$., the population is 682 thousand people. Mari El is a part of the Volga-Vyatka economic region, the geographical position of the Republic is shown in figure 1.

It should be noted that the authors focused on the manufacturing industry as the basis of the industrial complex of the region. The share of manufacturing in the total industrial production of the region amounted to $85 \%$ in 2018. In 2018, the manufacturing industry of the Republic was represented by 1606 enterprises. The largest number of enterprises is available in woodworking (347), metalworking (285), food industry (181), production of non-metallic mineral products (136), furniture production (127), repair and installation of machinery and equipment (100).

The aim of the study is to analyze the transformation of

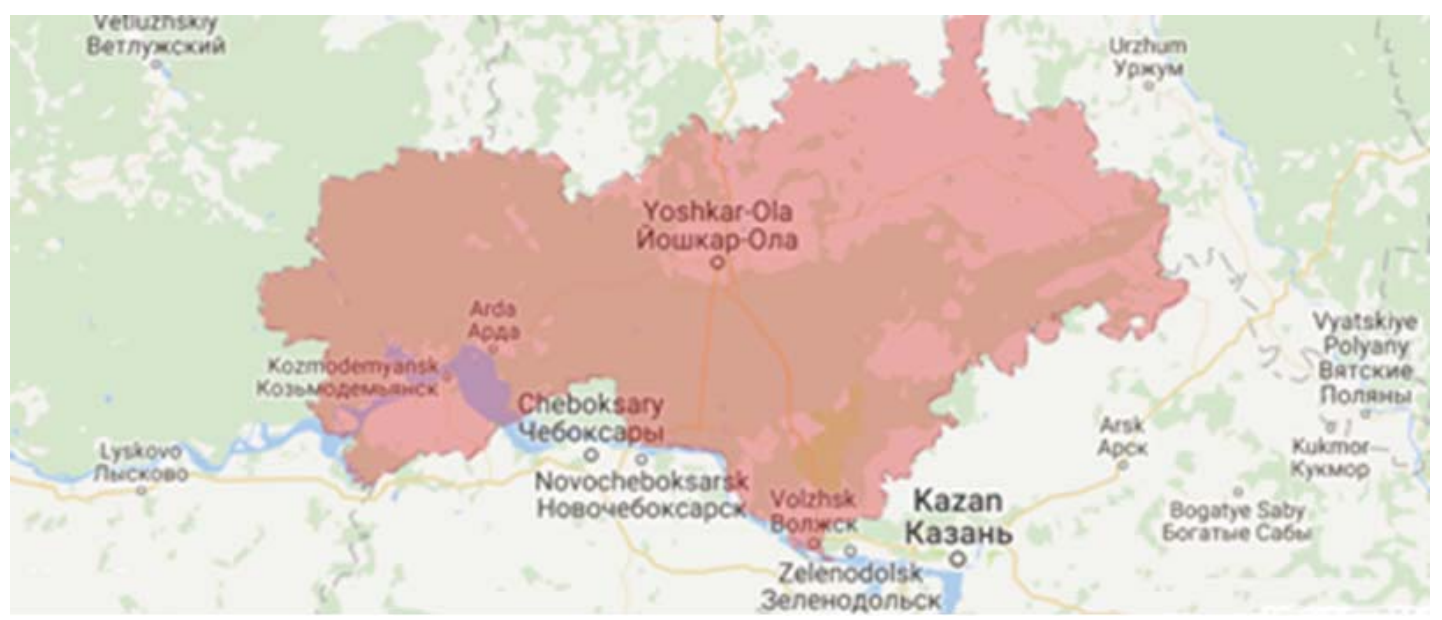

Figure 1: The Mari El Republic 
Deindustrialization is a characteristic trend for the Russian industry, which manifests itself in a decrease in the share of the industrial sector in GDP [28]. However, in the Mari El Republic for the period of 2010-2017 there is an increase in the manufacturing share in GRP (from $28.2 \%$ to $29.8 \%$ ). The share of people employed in the manufacturing industry increased from $18.9 \%$ to $19.7 \%$ over the same period. This shows that the industrial sector keeps playing an important role in the region's economy.

In the analysis of the transformation process of the Mari El Republic's industrial complex, it should be recognized that it is characterized by common problems of industrial development in Russia. Among the main problems is the increase in depreciation of fixed assets and low productivity compared to the leaders of the global competitiveness rating of the world and Russia. The current situation is a consequence of the economy structure, which has not been overcome since the Soviet times and which was focused on the military-industrial complex. As a rule, machine-building enterprises, which have a significant share of government orders in their production portfolio, act as engines of regional development. The formation of the Mari El Republic industrial complex structure was influenced by factors specific to the provincial region: insignificant capacity of the local market, significant payback periods for capital investments, high costs for infrastructure development of the territory, as well as high transport cost of the gross regional product.

Next, we consider the parameters of the dynamics and structure of the region's industrial complex, which are demonstrated by the processes of the regional production system transformation. The indices of industrial production, the share of the high-tech sector, material and technical equipment, innovation and investment potential, staffing and profitability of products demonstrate the general state of the region's production system.

The industrial complex of the region demonstrates stable growth rates during the analyzed period. Industrial production indices, except for 2016, exceed $100 \%$ (Fig. 2). The industrial production driver is the manufacturing industry, which shows stable growth rates, despite a slight decline in production in 2016. In general, in 2017, com- pared with the level of 2010 , growth in the manufacturing industry amounted to $61.4 \%$.

The share of the food industry (24\% in 2017) and the production of coke and petroleum products $(25.9 \%$ in 2017) increased in the Mari El Republic's manufacturing industry structure during the analyzed period (Fig. 3). At the same time, the share of machinery and equipment production decreased, but the share of electrical equipment production increased from $14 \%$ to $20.3 \%$.

According to the analysis of the high-tech sector (medicines and medical materials production; computers, electronic and optical products manufacturing) it had $10.2 \%$ in the Mari El Republic's manufacturing industry in 2018. Medium-technology sector (chemicals and chemical products manufacturing; electrical equipment manufacturing; machinery and equipment manufacturing; vehicles, trailers and semi-trailers manufacturing; repair and installation of equipment) had $17.4 \%$ [24].

There is a transformation of the region's industrial complex and a transition from the machine-building orientation, which took place in the second half of the 20th century, to the agro-industrial and light-industrial orientation. According to R. Prebisch, the main export goods of the periphery are raw materials and food [7]. In this regard, these trends indicate a decrease in the engineering potential of the region, strengthening of the "peripherality" of the economy.

The ability of manufacturing enterprises to transform and accept innovation depends on the material and technical equipment of production. The degree of depreciation of fixed assets in the republic increased to $47 \%$, which is a general trend in the whole country. The degree of fixed assets physical deterioration of the manufacturing industry in the region is lower than the average values in Russia (Fig. 4). At the same time, world practice shows that the level of depreciation of fixed assets at the level of $45-50 \%$ signifies a pre-crisis state of the industry. The fixed assets commissioning coefficient in the region is below the national average (Fig. 5), which is due to the extremely low level of investment in the manufacturing modernization (Fig. 6).

In $2017,25 \%$ of the total investment was directed to the

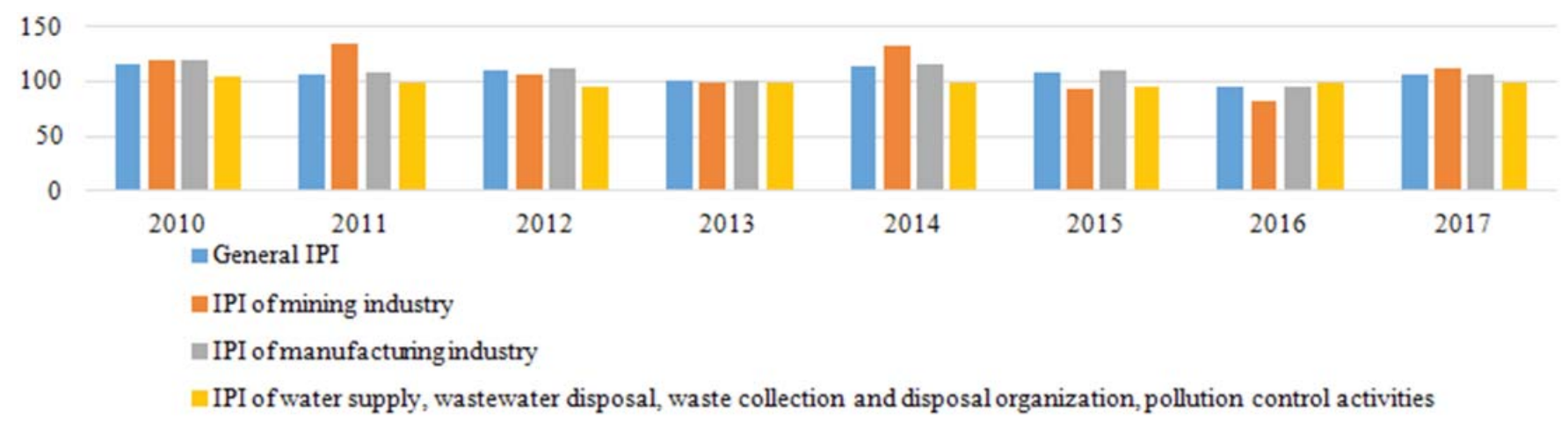

Figure 2: Industrial production indices (IPI) of the Mari EI Republic in 2010-2017, \%

(Compiled on the basis of data from the Russian Federation Federal State Statistics Service: http://www.gks.ru/) 


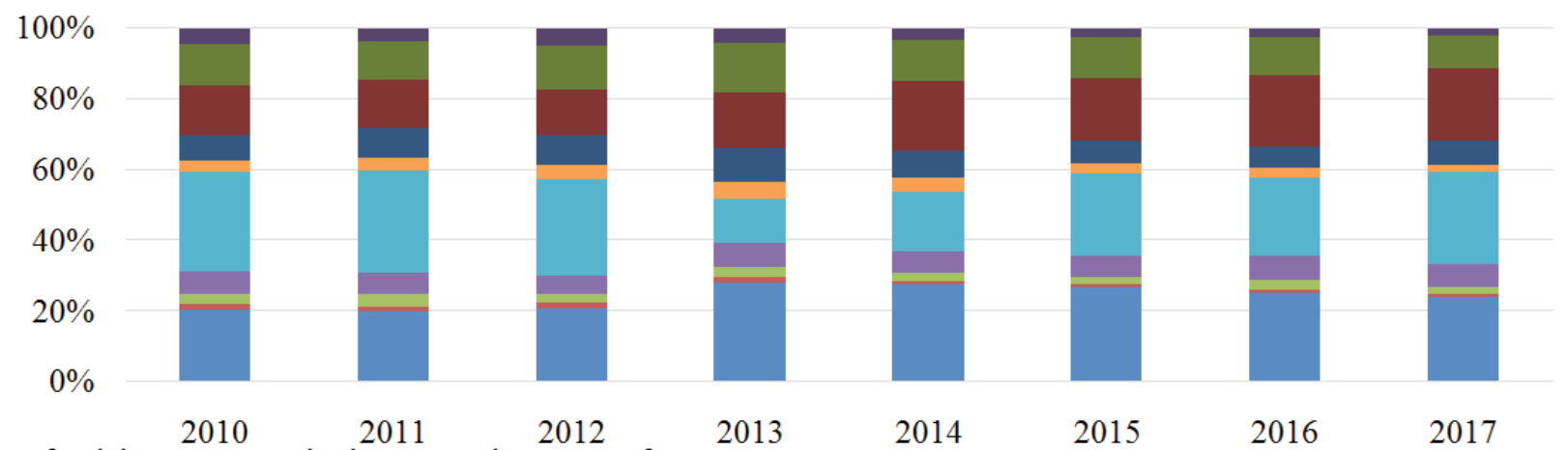

food, beverages and tobacco products manufacture

- textile manufacture; wearing apparel manufacture; leather and leather products manufacture

wood processing, wood and cork products manufacture, straws and materials for weaving manufacture

- paper and paper products manufacture; printing and copying media activities

coke and petroleum products manufacture; chemical production; rubber and plastic products manufacture

other non-metallic mineral products manufacture

metallurgical production; finished metal products manufacture, except machinery and equipment

- electrical, electronic and optical equipment manufacture

machinery and equipment manufacture, motor vehicles, trailers and semi-trailers manufacture, other vehicles and equipment manufacture

other production

Figure 3: Structure of shipped products of the Mari El Republic's manufacturing industry in 2010 - 2017, \% (Compiled on the basis of data from the Russian Federation Federal State Statistics Service: http://www.gks.ru/)

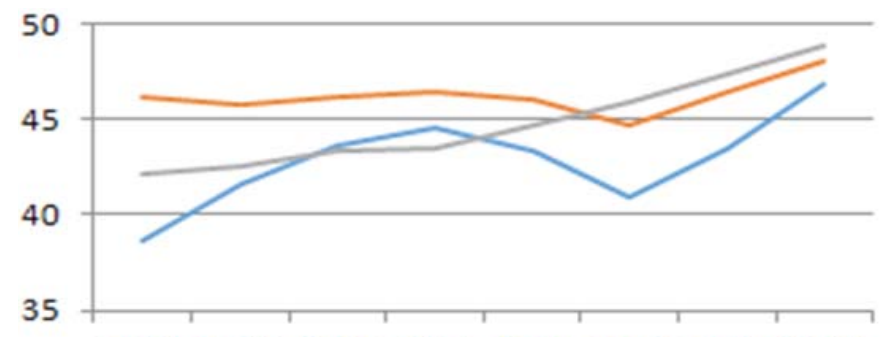

20102011201220132014201520162017

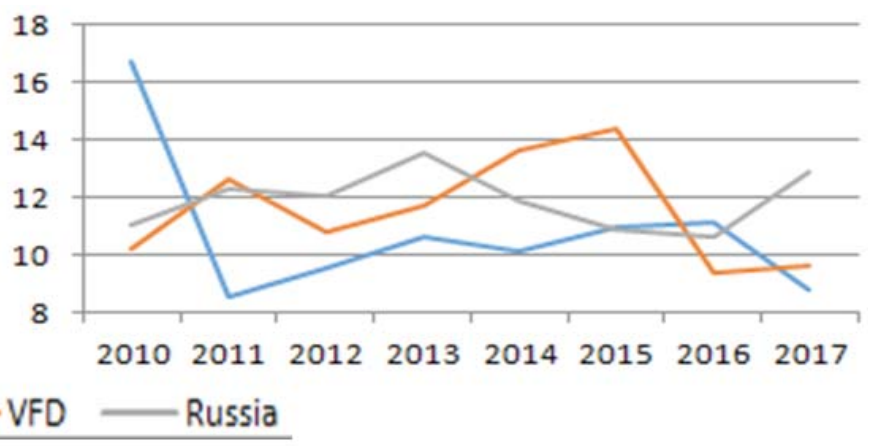

Figure 5: Fixed assets commissioning of, \%

Figure 4: Fixed assets depreciation, \%

(Compiled on the basis of data from the Russian Federation Federal State Statistics Service: http://www.gks.ru/, the Territorial Department of the Russian Federation Federal State Statistics Service for the Republic of Mari El: http:// maristat.gks.ru/)

manufacturing industry of the Republic. It should be noted that there is no growth in investment in technological innovations in the region, as opposed to the growth of this indicator in the VFD and Russia. In terms of investment in fixed capital per capita among 85 regions of Russia, the Republic took the 80th place [24].

To assess the impact of investments on the development of the industrial sector of the region's economy, a correlation analysis was used. Correlation coefficients were determined, namely coefficient R1 between the index of investments in 2010-2016 and the index of GRP in 2011-
2017, and R2 between the index of investment over the 2010-2016 and manufacturing production for 2011-2017. The impact of investment on economic system manifests itself with some delay, so the calculation of correlation coefficients between level of investment and result indicators are produced with a lag of one year. The relationship between the indicators can be estimated as high, since the values of the correlation coefficients $R 1=0.69$ and $\mathrm{R} 2=0.68$ were obtained..

Investments in technological innovations are especially important, but their main source in the region is the 


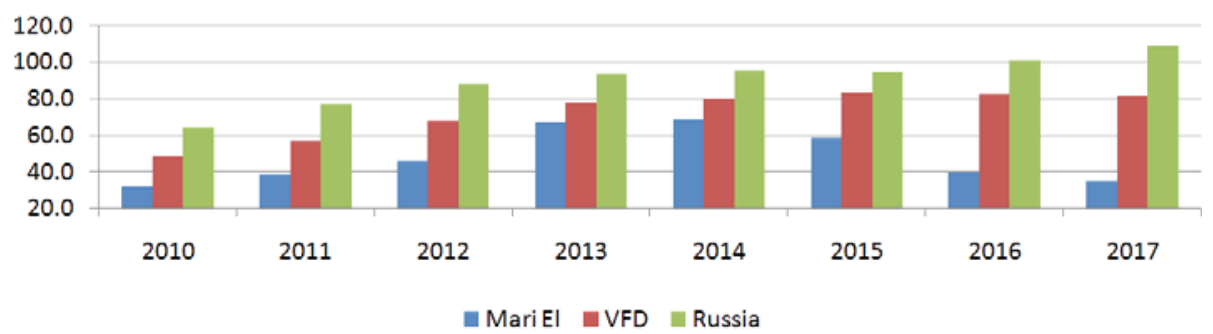

Figure 6: Investments in fixed capital per capita, thousand rubles

(Compiled on the basis of data from the Russian Federation Federal State Statistics Service: http://www.gks.ru/, Compiled on the basis of data from the Russian Federation Federal State Statistics Service: http://www.gks.ru/, the Territorial Department of the Russian Federation Federal State Statistics Service for the Republic of Mari El: http://maristat.gks.ru/)

own funds of enterprises. Business entities are limited in credit resources due to the high interest rate on bank loans with low profitability of production. In such circumstances, the manufacturing industry needs state support and programs of concessional lending to the high-tech sector of the economy.

Within the framework of the study, a correlation analysis was conducted to examine the relationship between the level of region's innovative development (according to the ratings of innovative regions of Russia AIRR[26]), the index of manufacturing and GRP. The analysis showed no significant correlation between the indicators, which means that the manufacturing industry of the Republic has a low innovative potential, which is not able to have a positive impact on the industry's development. The Mari El Republic is a region with a reduced share $(0.5-1 \%)$ in Russia's resources for the high-tech business development and a low share $(<0.5 \%)$ in the results of the Russian technology sector. In 2017, the Republic is on the 68th place in terms of technological business resources and on the 64th place in terms of technological business development in Russia. In fact, this demonstrates the weak position of the region in terms of the high-tech sector potential. The results are consistent with the results of monitoring of high-tech business, which refers the Mari El Republic to small centers of non-resource growth[27]. In the assessment of the characteristics of the personnel potential of the region's industrial complex, it is worth noting a low cost of wages in the region in comparison with the average values for the VFD and Russia should. In 2017, the average monthly nominal wage of employees in the Mari El republic in relation to the national average was only $65 \%$, which leads to the outflow of highly qualified personnel from the region.

The structure of the employed population by level of education generally corresponds to the situation in Russia. It is worth noting a smaller proportion of employees with higher education $(28.7 \%$ against $34.2 \%$ in Russia as a whole). At the same time, the share of workers with secondary vocational education, including those with working specialties, is higher than the average values in Russia. The sufficiency of the region's industrial complex with professional personnel with working professions and necessary competences contributes to its transformation[29].

As the resulting performance indicators of the region's industrial complex, we consider the profitability of products. The profitability of processing industries in the Republic on average is lower than the average data for Russia and VFD (Fig. 7). Due to the economic restrictions imposed by the EU on the Russian economy in 2014, Russia was forced to shift to import substitution in many sectors of the economy. The growth in profitability since 2014 is largely due to the implementation of import substitution policy in Russia, which led to the withdrawal of a number of competitors from the Russian market and increased demand for domestic products. Import substitution creates opportunities for the accumulation of capi-

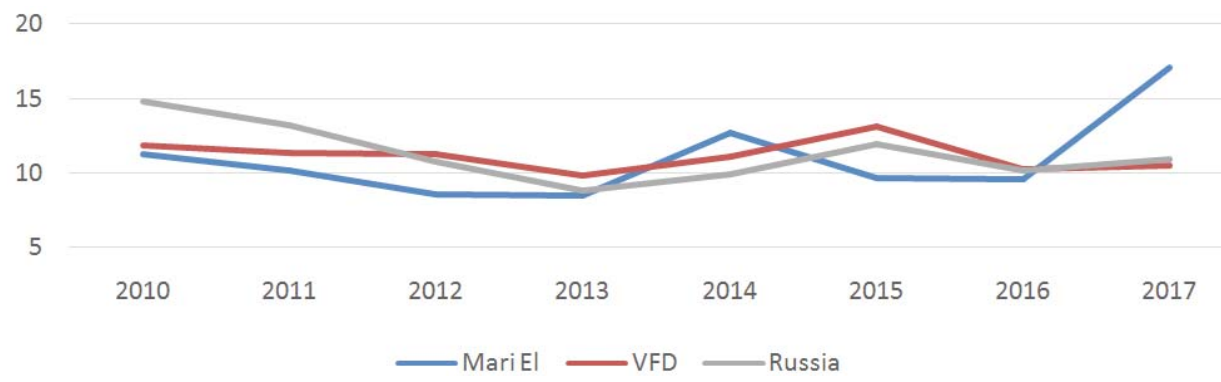

Figure 7: Profitability of manufacturing industry, \%

(Compiled on the basis of data from the Russian Federation Federal State Statistics Service: http://www.gks.ru/, Compiled on the basis of data from the Russian Federation Federal State Statistics Service: http://www.gks.rul, the Territorial Department of the Russian Federation Federal State Statistics Service for the Republic of Mari El: http://maristat.gks.ru/) 
tal that can be reinvested in technological development. The analysis shows the low potential of the manufacturing industry of the Mari El Republic, the need to strengthen the investment component and reinforce the innovation strategy of the region.

\section{The development strategies of the industrial complex of the Mari El Republic}

The analysis of the industrial complex of the Mari El Republic allowed to determine possible innovative strategies for its development. In the design process of development strategies, types of strategies proposed by Ch. Freeman \& L. Soete [30] and J. J. Lambin [31] we reused.
The variability of strategic decisions is determined by differences in the level of development of industrial sectors, the competitiveness of production systems. The region's enterprises, which are successfully transformed in accordance with industry trends 4.0., are able to implement an offensive strategy. The number of such modern production systems is very small. These are enterprises of the IT industry, companies producing electrical equipment, electronic and optical equipment (Table 1).

The existing industrial potential of the region is more in line with the intermediate strategy and import substitution strategy. The Mari El Republic has no valuable minerals reserves, explored hydrocarbon deposits, it is distant from the main transport routes. At the same time, the

Table 1: Development strategies of the industrial complex of the Mari El Republic

\begin{tabular}{|c|c|c|}
\hline The type of strategy & Characteristics of the strategy & $\begin{array}{l}\text { Region's industrial entities with the potential to } \\
\text { implement the strategy }\end{array}$ \\
\hline Offensive & 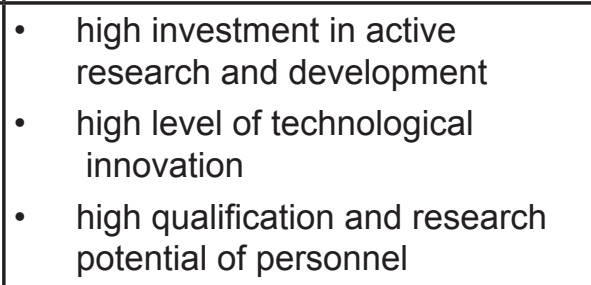 & $\begin{array}{l}\text { Enterprises of IT-sphere (TravelLine, iSpring), } \\
\text { electrical equipment production, electronic and } \\
\text { optical equipment production (Potential LLC, } \\
\text { NPO Tavrida electric JSC, Technotech LLC) }\end{array}$ \\
\hline Defensive & $\begin{array}{l}\text { high level of technological } \\
\text { development of companies } \\
\text { and industries in the region, } \\
\text { a significant share and strong } \\
\text { competitive position of regional } \\
\text { companies in foreign markets } \\
\text { concentration on improvement } \\
\text { of production technologies and } \\
\text { marketing, but not on venture } \\
\text { developments }\end{array}$ & $\begin{array}{l}\text { Machinery and equipment manufacturing, } \\
\text { electrical equipment manufacturing, } \\
\text { enterprises of the military-industrial complex, } \\
\text { production of metal products (MMZ JSC, OKTB } \\
\text { Crystal, Argus-Volga LLC), paper and paper } \\
\text { products manufacturing (Mari PPM JSC) }\end{array}$ \\
\hline Intermediate & 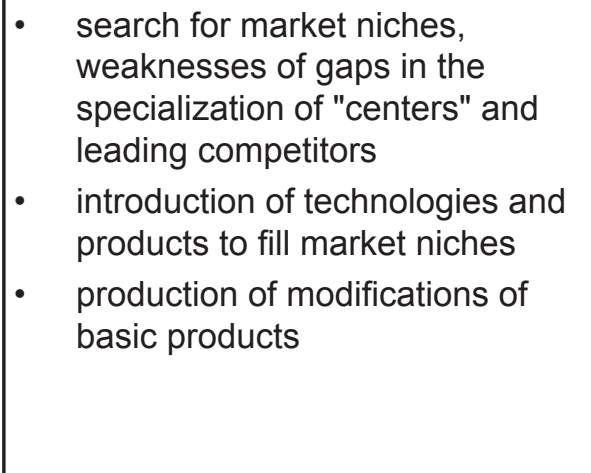 & $\begin{array}{l}\text { Electrical equipment manufacturing, electronic } \\
\text { and optical equipment manufacturing (ZPP JSC, } \\
\text { SKB Chromatek JSC), IT-sphere, production of } \\
\text { metal products (Portal JSC, Tiara LLC, } \\
\text { Krasnooktyabrsky plant of metal products JSC), } \\
\text { machinery and equipment manufacturing } \\
\text { (Contact JSC, Ariada JSC, Company } \\
\text { Polyus JSC, Moven PJSC), chemical production } \\
\text { (SHKHZ Siver JSC, Marbiopharm JSC), wood } \\
\text { processing and wood products manufacturing } \\
\text { (Guardian DOZ LLC, Investforest LLC) }\end{array}$ \\
\hline $\begin{array}{l}\text { Import innovations, } \\
\text { import substitution }\end{array}$ & 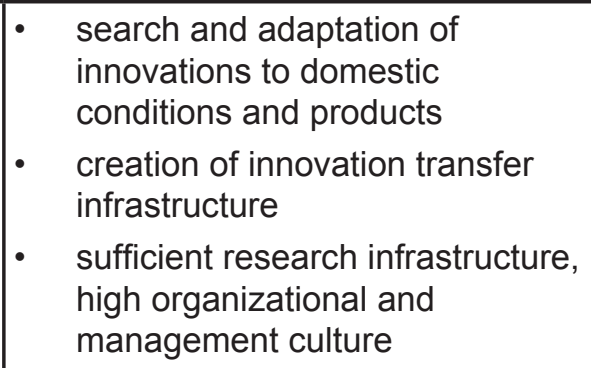 & $\begin{array}{l}\text { Small and medium-sized enterprises operating in } \\
\text { machinery and equipment manufacturing, } \\
\text { electrical equipment manufacturing, electronic } \\
\text { and optical equipment manufacturing, metal } \\
\text { products manufacturing, paper and paper } \\
\text { products manufacturing, chemical production, } \\
\text { enterprises of the military-industrial complex }\end{array}$ \\
\hline
\end{tabular}


region has advantages related to the characteristics of human capital and research potential. The low cost of labor and the presence of three universities with sufficient material and technical base which preparey a wide range of specialists, create conditions for technological modernization of the region's manufacturing industry through the adaptation of modern technologies.

The intermediate development strategy of the manufacturing industry can be based on stimulation of development of technological business in IT-sphere, in computer equipment production, electric equipment production, electronic and optical equipment production, metal products manufacturing, machinery and equipment production, chemical production, processing of wood and wood products manufacturing in the region.

The efforts of the regional leadership should be aimed at the implementation of the policy of self-sustaining growth, development of own production and import substitution. Such a scenario can be implemented by providing import substitution in low and medium-tech industries, preferential taxation and subsidizing the credit rate in the end-consumer sectors of with high added value, as well as attracting foreign investment and developing infrastructure to support innovation and technological entrepreneurship in the region.

\section{SUMMARY AND CONCLUSION}

Analysis of the dynamics and structure of the region's industrial complex leads to the conclusion that the process of the region's production system transformation has the following characteristics:

1. increase in the fixed assets depreciation, low investment and innovation;

2. outflow of the population with higher education from the region due to low wages and sufficiency of the region's industrial complex with personnel of skilled labor at low cost;

3. enterprises of the high-tech sector of the region's industry (IT-sphere, enterprises for the electrical equipment production, electronic and optical equipment production) are able to implement an offensive strategy of innovative development;

4. enterprises of medium and low-tech industrial sectors are able to implement an intermediate strategy and strategy for import substitution.

Successful transformation of the region's industrial complex should be focused on the implementation of self-sustaining growth, which is impossible without state support of innovation and investment activity and technological entrepreneurship in the region.

\section{ACKNOWLEDGMENTS}

The study was funded by RFBR according to the research project № 19-010-00476 "Designing alternative scenarios of innovative development for a provincial region on the basis of the comparative and multivariate statistical analysis".

\section{REFERENCES}

1. https://base.garant.ru/70643464/2019 Apr 20.

2. https://www.garant.ru/products/ipo/prime/doc/71570570/ 2019 Apr 20.

3. https://asi.ru/upload/iblock/4b2/DK_TechNet.pdf 2019 Apr 20.

4. Kolosovsky N.N., (1969). The theory of economic zoning. Moscow: Thought.

5. Yakovets Yu.V., (2011). Global Economic Transformations of the XXI Century. Moscow: Ekonomika.

6. Trachuk A.V., Linder N.V., , Tarasov I.V., , \& et. al., (2018). The transformation of industry in the fourth industrial revolution. St. Petersburg: Publishing House "Real Economy".

7. Prebisch R., (1988). Dependence, development, and interdependence. U Schultz T.P. \& Ranis G. (Ur.), The state of development economics: Progress and Perspectives. (str. 31-48). Oxford: John Wiley and Sons Ltd.

8. Perroux F., (2017). The pole of development's new place in a general theory of economic activity. U Higgins B. \& Savoie D. J. (Ur.), Regional Economic Development: Essays in Honour of Francois Perroux. (str. 48-76). London, UK: Routledge.

9. Rostow W.W., (1985). The World Economy since 1945: A Stylized Historical Analysis. The Economic History Review, 38(2), 252-275.

10. Mensch G., (1979). Stalematein Technology: Innovations Overcome the Depression. Cambridge, Massachusetts: Cambridge.

11. Sapir J., (2005). Diversity of trajectories and the path effect: Post-Soviet transitions [Diversité des trajectoires et effet de sentier: Les transitions post-Soviétiques]. Revue d'Etudes Comparatives Est-Ouest, 36(2), 177-208.

12. Kemp R., (2011). Innovation for sustainable development as a topic for environmental assessment. Journal of Industrial Ecology, 15(5), 673-675.

13. Hegyi-Kéri A., (2013). Regional Specialization and Geographic Concentration of Economic Sectors in the Visegrád Countries. 'Club of Economics in Miskolc' TMP, 9(1), 31-41.

14. Vujosevic M., \& Petovar K., (2010). European planning discource and a renewal of European sustainable development planning: some lessons for a transition country (Serbia). Sociology and Space, 48(2), 173-195.

15. Sarra A., Di Berardino C., \& Quaglione D., (2019). Deindustrialization and the technological intensity of manufacturing subsystems in the European Union. Economia Politica, 36(1), 205-243. doi:10.1007/ s40888-018-0112-8 
16. Beg M., Sertic M.B., \& Druzic I., (2017). Determinants of deindustrialisation in developed European and post-communist countries. Montenegrin Journal of Economics, 13(2), 93-106.

17. Lošonc A., \& Ivanišević A., (2014). Deindustrialization: Why would anyone it is a myth. International Journal of Industrial Engineering and Management, 5(1), 29-38.

18. Tomljanović M., Grubišić Z., \& Huđek I., (2018). Process of Deindustrialization in Montenegro. Journal of Central Banking Theory and Practice, 7(2), 99-121. doi:10.2478/jcbtp-2018-0014

19. Glaziev S. Yu., (1993). Theory of long-term technical and economic development. Moscow: VlaDar.

20. Polterovich V.M., (2007). Elements of Reform Theory. Moscow: Ekonomika.

21. Kleiner G.B., (2017). System transformation of industry as a "solid core" of the domestic economy. Scientific Works of the Free Economic Society of Russia, 207(5), 210-223.

22. Sukharev O.S., (2018). Estimation of the level of industrialization of regional economy and regional industrial policy. U: Economic Policy and Resource Potential of the Region. Bryansk: Bgitu.152-163.

23. Maslikhina, V. [2017]. Spatial concentration of the manufacturing industry: Evidence from Russia. Journal of Applied Engineering Science, 15(4), 509-517.
24. http://www.gks.ru/ 2019 May 20.

25. http://maristat.gks.ru/wps/wcm/connect/rosstat_ts/ maristat/ru/ 2019 May 20.

26. http://i-regions.org/eng/ratings/rating-of-innovation-development 2019 May 24.

27. https://www.ranepa.ru/images/News/2019-03/2403-2019-nacdoklad.pdf 2019 May 20.

28. Akberdina V., Kalinina A., \& Vlasov A., (2018). Transformation stages of the Russian industrial complex in the context of economy digitization. Problems and Perspectives in Management, 16(4), 201-211.

29. Tsvetkova G.S., Murtazina, A.S., \& Grozova O.S., (2019). Theoretical and methodological aspects of the study of key competences of the region. Vestnik of Volga State University of Technology. Series "Economy and Management", 1, 30-39. doi:10.25686 / 2306-2800.2019.1.30

30. Freeman Ch., \& Soete L., (1997). The Economics for Industrial Innovation. Cambridge: MIT Press.

31. Lambin J. J., (2000). Market-driven management: Strategic and operational marketing. London: Macmillan press. 